Artikel Penelitian

\title{
Ekstraksi Zat Warna Alami dari Kayu Bakau (Rhizophora mucronata) dengan Metode Microwave-Assisted Extraction
}

\author{
Yuyun Yuniati ${ }^{1}$, Maulidya D. Cahyani², Ifra Novidayasa², Pantjawarni Prihatini², Mahfud Mahfud2* \\ 1Program Studi Kimia, Fakultas Sains dan Teknologi, Universitas Ma Chung, Malang, Indonesia, 65151 \\ 2Departemen Teknik Kimia, Fakultas Teknologi Industri, Institut Teknologi Sepuluh Nopember Surabaya, Indonesia, 60117
}

INFO ARTIKEL

\section{Riwayat Artikel}

Diterima 16 Desember 2020

Direvisi 2 Februari 2021

Tersedia online 5 Mei 2021

\footnotetext{
* Penulis korespondensi: mahfud@chem-eng.its.ac.id
}

\section{ABSTRAK}

Dyes are widely used for various manufacturing processes. However, the high use of synthetic dyes has resulted in pollution and health problems. To overcome this problem, one way that can be done is to return to using natural dyes. Natural dyes can be obtained from various plants, one of which is the Indonesian mangrove plant (Rhizophora mucronata). This research has succeeded in extracting natural dyestuffs from mangrove bark using the microwave-assisted extraction method. Mangrove wood extraction was carried out with solvents, namely distilled water and ethanol $96 \%$, which was optimized based on the ratio of sample mass to volume of solvent and extraction power. The results showed that qualitatively the mangrove extract contained tannins, flavonoids, and quinones as compounds that gave chocolate color. The color resistance of mangrove extracts is very strong in textiles under alkaline conditions. Based on the results of extraction optimization, the optimum conditions were obtained at a ratio of $0.067 \mathrm{~g} / \mathrm{mL}$ of $96 \%$ ethanol at 380 watts of power, with a yield percentage reaching $53.053 \%$.

Keywords: extraction, mangrove wood, microwave

Zat warna banyak digunakan untuk berbagai proses manufaktur. Namun, tingginya penggunaan zat pewarna sintetis mengakibatkan pencemaran dan masalah kesehatan. Untuk mengatasi masalah tersebut, salah satu cara yang dapat dilakukan adalah kembali menggunakan zat warna alami. Zat pewarna alami dapat diperoleh dari berbagai tumbuhan, salah satunya tanaman bakau Indonesia (Rhizophora mucronata). Penelitian ini telah berhasil melakukan ekstraksi zat warna alami kulit kayu bakau dengan metode microwave-assisted extraction. Ekstraksi kayu bakau dilakukan dengan pelarut yaitu akuades dan etanol $96 \%$ yang dioptimasi berdasarkan rasio massa sampel-volume pelarut dan daya ekstraksi. Hasil penelitian menunjukkan bahwa secara kualitatif ekstrak kayu bakau mengandung tanin, flavonoid, dan kuinon sebagai senyawa pemberi warna coklat. Ketahanan warna ekstrak kayu bakau sangat kuat pada bahan tekstil pada kondisi basa. Berdasarkan hasil optimasi ekstraksi, kondisi optimum didapatkan pada rasio massa sampel-volum pelarut sebesar $0,067 \mathrm{~g} / \mathrm{mL}$ dan daya sebesar 380 Watt sehingga diperoleh persentase yield mencapai $53,053 \%$.

Kata kunci: ekstraksi, kayu bakau, microwave 


\section{Pendahuluan}

Zat warna dianggap sebagai suatu bahan yang dapat meningkatkan nilai jual suatu produk, termasuk produk tekstil, kosmetik, pangan, dan peralatan rumah tangga [1,2]. Dalam satu dekade terakhir ini, penggunaan zat warna sintetik untuk proses manufaktur masih sangat tinggi dibandingkan dengan zat warna alami, dimana konsumsi zat warna alami setara dengan $1 \%$ dari jumlah total konsumsi zat warna sintetis global [3]. Sayangnya, dampak pencemaran maupun kesehatan yang dihasilkan oleh zat warna sintetik akan semakin terus meningkat jika produksi jenis zat warna ini dibiarkan terus menerus. Maka dari itu, industri masa kini ditantang untuk kembali menerapkan penggunaan zat warna alami dalam proses produksi produk yang bersifat tidak beracun dan biodegradable [4].

Keterbatasan jumlah sumber daya alam menjadi salah satu hambatan produsen global dalam memperoleh bahan baku produksi zat warna alami [5]. Indonesia merupakan salah satu negara yang dikaruniai kekayaan flora secara melimpah sehingga zat warna alami dapat diperoleh secara mudah [6]. Zat warna alami dapat diperoleh dari berbagai bagian pokok tumbuhan, mulai dari kulit, ranting, batang, daun, akar, biji, bunga, hingga getah. Pohon bakau (Rhizophora mucronata) menjadi salah satu tumbuhan yang cukup banyak persebarannya di Indonesia dengan perkiraan luas hutan mangrove mencapai 4,25 juta hektar [7]. Pada kulit kayu bakau mengandung senyawa tanin, flavonoid dan kuinon sebagai sumber zat warna coklat alami [8]. Keberadaan kulit kayu bakau Indonesia dapat menjadi suatu potensi besar untuk dimanfaatkan sebagai bahan baku produksi zat warna alami.

Berkaitan dengan perolehan zat warna alami suatu tumbuhan, saat ini proses ekstraksi dapat dilakukan dengan beberapa metode, seperti metode maserasi, soxhlet, dan sonikasi $[9,10]$. Metode microwave-assisted extraction (MAE) merupakan metode ekstraksi yang memanfaatkan energi gelombang mikro dengan frekuensi $0,03-300 \mathrm{GHz}$ sebagai cara untuk memperoleh zat ekstrak dari hasil proses difusi zat pelarut ke dalam dinding sel. Metode ini memiliki keunggulan dalam perolehan yield yang tinggi dan waktu ekstraksi yang lebih cepat jika dibandingkan dengan metode soxhlet [11, 12]. Penelitian Jyothi dkk [13] menyatakan perolehan yield zat ekstrak dengan metode MAE dapat mencapai $69 \%$ untuk waktu ekstraksi 2 menit, sedangkan dengan metode soxhlet memperoleh yield $16 \%$ dengan waktu ekstraksi 14 jam.

Optimasi ekstraksi dengan metode MAE menjadi hal yang penting dilakukan untuk memperoleh zat ekstrak dengan presentase yield setinggi-tingginya [14]. Berbagai aspek perlu dipertimbangkan dalam proses esktraksi zat warna alami, seperti penggunaan bahan pelarut dan spesifikasi daya operasi alat MAE [15]. Kedua aspek ini dianggap mampu memengaruhi efektivitas laju ekstraksi zat warna alami suatu tumbuhan. Oleh karena itu, penelitian ini bertujuan untuk memperoleh zat warna alami pada kondisi ekstraksi yang optimal dari kulit kayu bakau Indonesia. Sebagai studi pendahuluan, ekstrak zat warna alami yang diperoleh mula-mula dianalisis secara kualitatif untuk memastikan keberadaan kandungan senyawa pemberi warna coklat kulit kayu bakau, serta dilanjutkan dengan uji ketahanan warna dengan zat warna sintetik sebagai pembanding.

\section{Bahan dan Metode}

\subsection{Bahan}

Pada penelitian ini digunakan kulit kayu bakau yang dikeringkan di bawah sinar matahari selama tiga hari. Analisis kualitatif dan uji ketahanan warna dilakukan dengan bahan larutan besi klorida $\left(\mathrm{FeCl}_{3}\right)$, asam sulfat $\left(\mathrm{H}_{2} \mathrm{SO}_{4}\right)$, natrium hidroksida $(\mathrm{NaOH})$, natrium klorida $(\mathrm{NaCl})$, asam sitrat, tawas, dan sabun. Akuades dan etanol $96 \%$ digunakan untuk bahan utama dalam melakukan proses optimasi ekstraksi. Metode ekstraksi yang digunakan adalah batch extraction.

\subsection{Ekstraksi Sampel}

Penelitian ini menggunakan metode microwave-assisted extraction (MAE) seperti penelitian yang terdahulu [11,16, $17,18]$. Tahap awal yang harus dilakukan yaitu menimbang bahan sebanyak $10 \mathrm{~g}$. Kemudian, bahan tersebut dimasukkan ke dalam labu leher tiga dan ditambahkan pelarut aquades. Ekstraksi dilakukan di dalam labu leher tiga dengan pengaturan daya microwave 100, 240, dan 380 Watt selama 15 menit. Hasil ekstrak kemudian ditampung dan disaring dengan menggunakan kertas saring. Filtrat yang diperoleh kemudian dipanaskan dengan menggunakan hot plate $\left(70^{\circ} \mathrm{C}\right)$ hingga menjadi serbuk. Serbuk yang diperoleh ditimbang dan data massa digunakan untuk menghitung persentase yield.

\subsection{Uji Ketahanan Warna}

Uji ketahanan warna dilakukan dengan variabel suasana asam, basa, dan netral pada helaian kain katun berukuran $8 \times 10 \mathrm{~cm}$. Pengujian ketahanan luntur warna dilakukan dengan pencucian dengan air panas bersuhu $70-80^{\circ} \mathrm{C}$ dengan sabun sambil dilakukan pengadukan perlahan selama \pm 15 menit. 


\subsection{Analisis GC-MS}

Analisis ini bertujuan untuk mengidentifikasi komponen-komponen yang terdapat pada serbuk zat pewarna yang dihasilkan [19, 20, 21, 22]. Komponen zat warna dari produk hasil ekstraksi ditentukan dengan kromatografi gas yang digabungkan dengan analisis spektrometri massa (GC-MS) Instrumen Agilent 6890N Sistem Jaringan GC, Kolom GC Kapiler J \& W Agilent (30 mm x 0,320 mm x 0,25 $\mu \mathrm{m}$ ). Sampel dikocok dan diambil 0,11 $\mu \mathrm{L}$ dan diinjeksikan ke dalam instrumen. Kondisi yang dipertahankan adalah: gas pembawa Alpha Gaz Helium Ultra murni; membagi 1 : 100; suhu injeksi $280^{\circ} \mathrm{C}$; suhu oven diprogram dari $50-230^{\circ} \mathrm{C}$ pada $5^{\circ} \mathrm{C}$ menit- ${ }^{-1}$ an $230-280^{\circ} \mathrm{C}$ pada $10^{\circ} \mathrm{C}$ menit- ${ }^{-1}$.

\section{Hasil dan Pembahasan}

\subsection{Pengaruh Jenis Pelarut terhadap Yield Ekstraksi}

Jenis pelarut yang digunakan dalam penelitian ini adalah akuades dan etanol 96\%. Berdasarkan Gambar 1 dapat terlihat bahwa yield yang diperoleh dengan menggunakan pelarut etanol $96 \%$ lebih tinggi jika dibandingkan dengan yield yang diperoleh dengan menggunakan akuades. Hal ini dipengaruhi oleh nilai konstanta dielektrik pelarut, dimana pelarut akuades memiliki konstanta dielektrik yang lebih tinggi dari pelarut etanol (konstanta dielektrik pelarut akuades adalah 78,3 dan pelarut etanol adalah 24,3) [23]. Konstanta dielektrik memengaruhi tingkat kepolaran suatu pelarut. Semakin polar pelarut yang digunakan maka kemampuan untuk menyerap gelombang mikro juga semakin besar.

Pada ekstraksi dengan pelarut akuades, gelombang mikro akan lebih banyak terserap oleh pelarut sehingga gelombang mikro belum dapat mencapai bahan dan menyebabkan pergerakan molekul yang terjadi di dalam bahan kurang maksimum dan berakibat pada proses ekstraksi tidak berjalan dengan optimum. Adapun pada pelarut etanol 96\%, konstanta dielektrik yang dimiliki lebih kecil sehingga mengakibatkan kemampuan menyerap gelombang mikro juga lebih rendah, sehingga yield yang diperoleh dapat meningkat [24, 25]. Hal ini dibuktikan dengan selisih perbedaan rata-rata yield yang dihasilkan yakni $16 \%$.

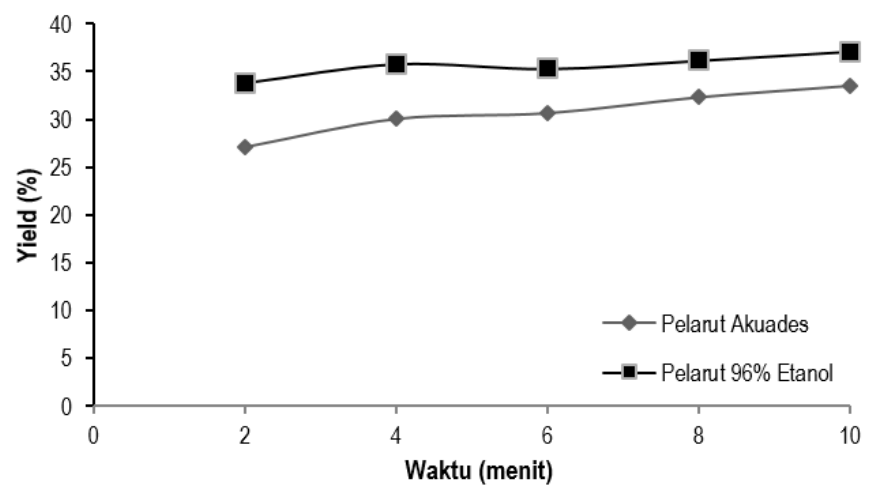

Gambar 1. Pengaruh jenis pelarut terhadap \% yield zat warna dengan variasi waktu pada rasio 0,033 (g/mL)

\subsection{Pengaruh Nilai Rasio dan Daya MAE terhadap Yield Ekstraksi}

Berdasarkan Gambar 2 dapat diketahui bahwa perbedaan nilai rasio dan daya MAE memberikan keberagaman hasil persentase yield. Namun, secara khusus dapat diketahui adanya persamaan profil dari perbedaan nilai rasio. Dalam hal ini, ekstrak zat warna dapat diperoleh secara optimum pada penggunaan rasio $0,133 \mathrm{~g} / \mathrm{mL}$ dalam pelarut akuades dan $0,067 \mathrm{~g} / \mathrm{mL}$ dalam pelarut etanol $96 \%$. Hal ini menunjukkan bahwa terdapat pengaruh rasio bahan dengan perolehan yield hasil ekstraksi zat warna coklat kulit kayu bakau, sesuai dengan penelitian Kusuma dan Mahfud [26].

Pengaruh rasio terhadap yield dapat dikaitkan dengan konsep sifat kelarutan dan titik jenuh yang memengaruhi proses ekstraksi zat warna pada sampel $[13,25]$. Pada rasio $0,067 \mathrm{~g} / \mathrm{mL}$ untuk bahan pelarut etanol diduga telah mencapai titik jenuhnya, sehingga persentase yield yang diperoleh pada rasio yang lebih tinggi, yakni 0,100 dan $0,133 \mathrm{~g} / \mathrm{mL}$ cenderung mengalami penurunan. Berkaitan dengan perbedaan daya MAE, secara umum dapat diketahui bahwa penggunaan daya MAE 240 dan 380 Watt memberikan persentase yield yang lebih tinggi dibandingkan dengan daya 100 Watt. Dalam penelitian ini, kondisi ekstraksi terbaik yaitu pada pelarut etanol $96 \%$ dengan rasio terbaik adalah $0,067(\mathrm{~g} / \mathrm{mL})$ pada daya 380 Watt dengan persentase yield sebesar 53.053\%. 


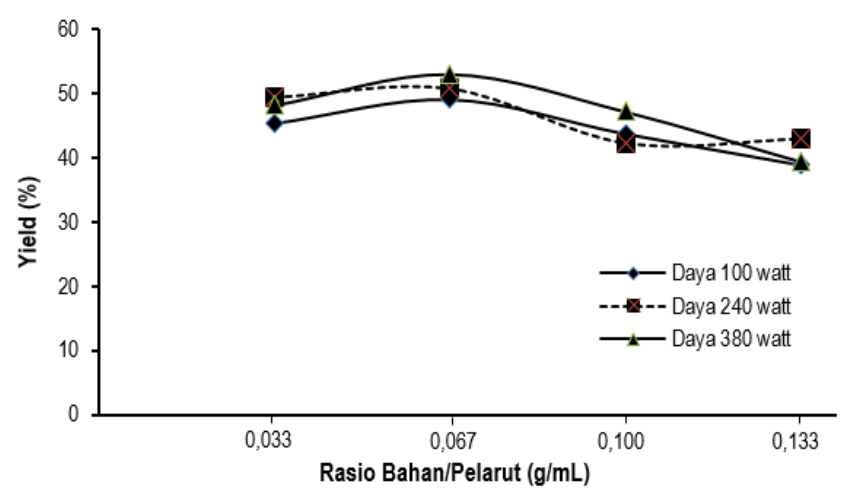

(a)

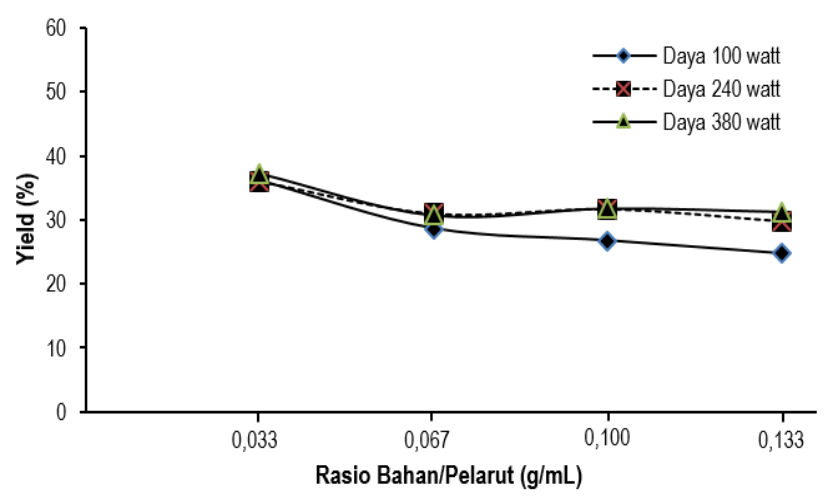

(b)

Gambar 2. Pengaruh rasio terhadap \% yield zat warna pada berbagai daya pada pelarut (a) akuades dan (b) etanol $96 \%$

\subsection{Analisis Kualitatif Ekstrak Zat Warna Kulit Kayu Bakau}

Metode pengujian dalam menentukan keberadaan kandungan tanin, flavonoid dan kuinon merupakan rangkaian dari uji fitokimia [19]. Pengujian ini dilakukan dengan mengambil sampel hasil ekstraksi menggunakan pelarut etanol dengan pertimbangan perolehan yield yang dihasilkan lebih tinggi jika dibandingkan dengan pelarut akuades. Hasil pengujian kualitatif yang ditunjukkan dalam Tabel 1 yang mengindikasikan bahwa ekstrak kulit kayu bakau secara positif mengandung senyawa aktif yang merupakan zat warna coklat dari hasil ekstraksi.

Pada analisis deteksi kandungan senyawa tanin terhadap sampel ekstrak, maka terbentuk warna hijau kehitaman setelah penambahan $\mathrm{FeCl}_{3}$, yang mana perubahan warna sampel ini terjadi akibat adanya pembentukan senyawa kompeks gugus polifenol senyawa tanin dalam ekstrak kulit kayu bakau dengan ion $\mathrm{Fe}^{3+}$ [20]. Pada uji kandungan senyawa flavonoid, warna sampel ekstrak kulit kayu bakau berubah menjadi kemerahan, sebagai indikasi adanya interaksi $\mathrm{H}_{2} \mathrm{SO}_{4}$ dengan senyawa flavonoid dalam sampel. Sedangkan untuk pengujian senyawa kuinon, warna sampel berubah menjadi merah pekat, sebagai indikasi positif adanya kandungan senyawa kuinon pada sampel ekstrak kulit kayu setelah penambahan larutan $\mathrm{NaOH} 1 \%$ [21, 22].

Tabel 1. Hasil Analisis Kualitatif Ekstrak Kulit Kayu Bakau

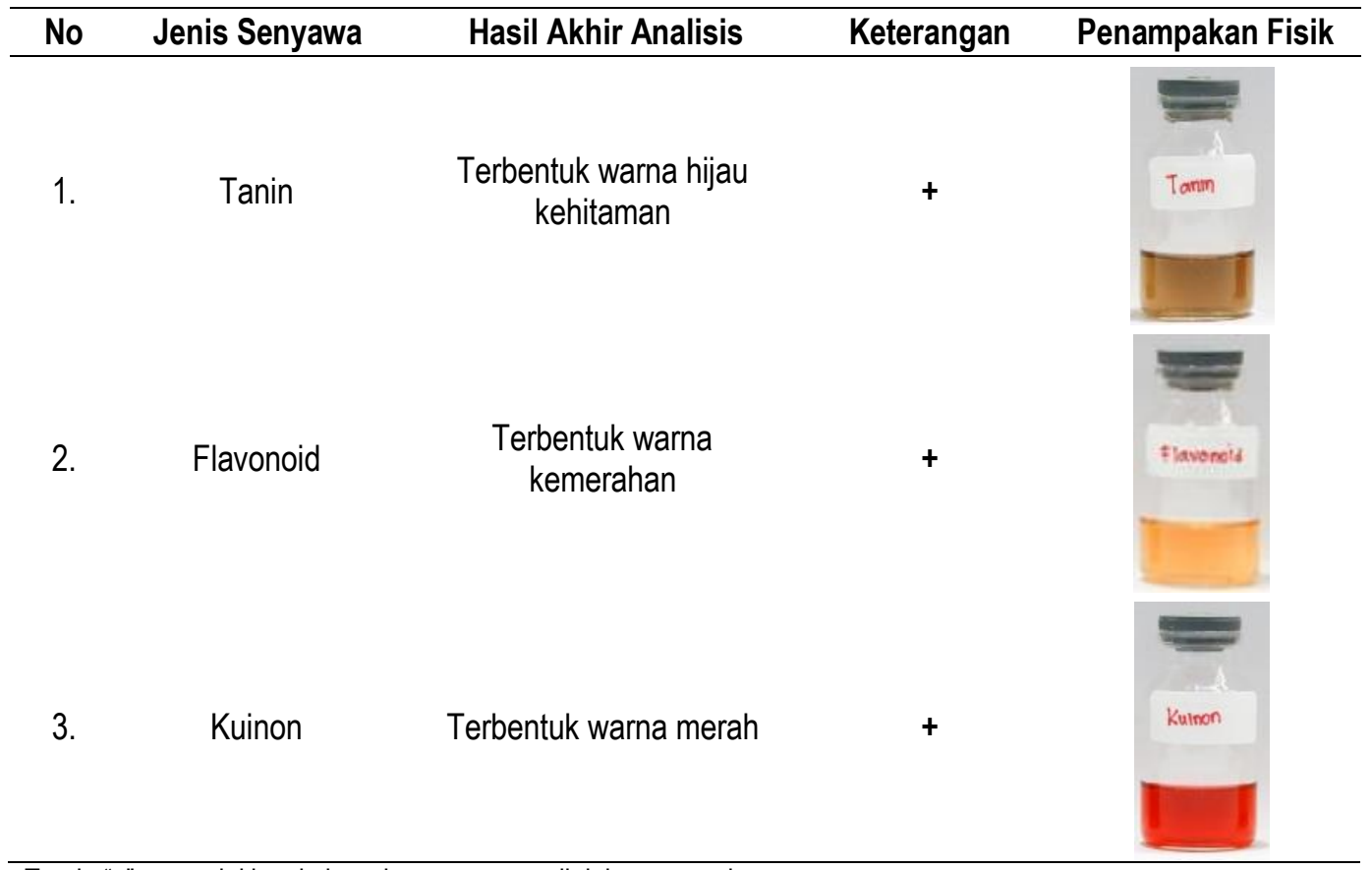

Tanda "+" menunjukkan keberadaan senyawa uji dalam sampel

\subsection{Uji Ketahanan Zat Pewarna Alami Esktrak Kulit Kayu Bakau}

Ketahanan luntur warna merupakan unsur yang sangat menentukan mutu suatu zat warna pada bahan tekstil. Kain katun digunakan dalam pengujian ketahanan warna, yang mana katun mengandung $94 \%$ serat selulosa. Selulosa memiliki gugus hidroksil cukup banyak sehingga mempunyai sifat higroskopis, sehingga hal ini menyebabkan zat warna dapat 
terserap dengan baik pada kain. Ikatan hidrogen baik yang terbentuk antara selulosa dengan suatu zat warna ketika proses perendaman menyebabkan zat warna yang memiliki ketahanan kuat akan sulit keluar dari serat, walaupun telah dilakukan pencucian dengan sabun, sehingga hal ini mengindikasikan bahwa zat warna dalam tekstil tidak mudah luntur [27].

Dalam proses pewarnaan kain terjadi proses fiksasi. Fiksasi merupakan tahapan paling penting setelah proses pencelupan warna yang bertujuan untuk mengunci warna. Penggunaan larutan fiksasi dalam proses pewarnaan kain akan membuat warna menjadi tidak mudah pudar dan tahan terhadap gosokan. Pada tahapan fiksasi pewarna digunakan tawas. Penggunaan tawas ini berfungsi untuk menjaga warna agar tidak mudah luntur pada proses pencucian. Hal ini dikarenakan terjadinya ikatan antara senyawa tanin dari ekstrak kulit kayu bakau dengan serat kain secara maksimum. Selain itu, adanya $\mathrm{Al}^{3+}$ dari larutan tawas akan menyebabkan terjadinya ikatan antara ion dengan tanin sehingga molekul zat pewarna alam yang berada di dalam serat menjadi lebih besar, dan menyebabkan molekul zat pewarna alam akan sukar keluar dari pori-pori serat dan akan memperkuat ketahanan warna dari efek luntur [28].

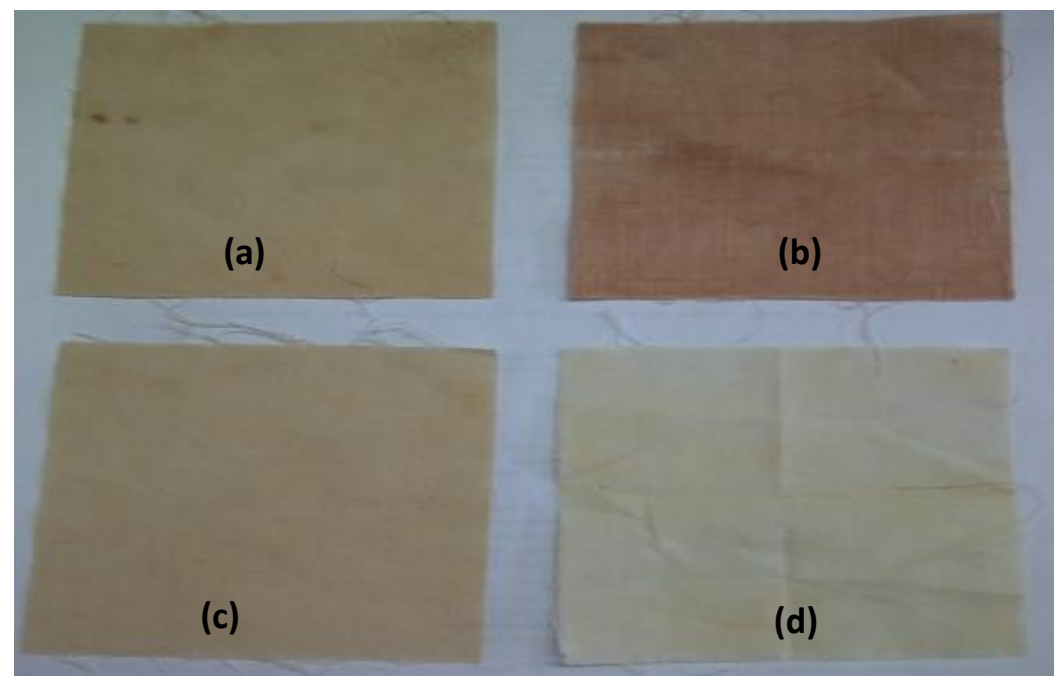

Gambar 3. Hasil uji ketahanan warna (a) asam, (b) basa, (c) netral, dan (d) pewarna sintetis

Pengujian ketahanan warna menggunakan sampel hasil ekstraksi dengan pelarut etanol. Pada pengujan ketahanan warna digunakan larutan asam kuat $(\mathrm{HCl})$ dan basa kuat $(\mathrm{NaOH})$. Pada proses fiksasi digunakan tawas terlebih dahulu agar zat warna lebih kuat ikatannya dengan kain, dan dilanjutkan dengan pengujian ketahanan warna. Berdasarkan Gambar 3, kain hasil pewarnaan pada suasana basa memiliki warna yang lebih gelap jika dibandingkan dengan kain hasil pewarnaan dengan suasana asam dan netral. Hal ini menunjukkan bahwa $\mathrm{pH}$ yang digunakan dalam proses pewarnaan sangat memengaruhi hasil ketahanan warna. Pada kondisi basa, zat tanin dan flavonoid memiliki kemampuan daya lekat lebih baik dibandingkan pada suasana asam maupun netral [28].

Berkaitan dengan pewarna sintetis, hasil uji ketahanan warna menunjukkan warna yang dihasilkan terlihat paling terang. Hal ini terjadi sebagai akibat dari pewarna sintetis yang digunakan memiliki kualitas warna yang lebih rendah jika dibandingkan dengan pewarna alami. Secara umum, pewarna alami memberikan hasil lebih redup, namun ada beberapa jenis pewarna alami yang dapat menimbulkan pewarnaan kuat, salah satunya adalah pigmen tanin yang ada di dalam kayu bakau.

\subsection{Analisis Ekstrak Etanol dengan GCMS}

Secara teoritis terdapat perbedaan antara senyawa aktif yang terekstrak pada etanol dan akuades karena adanya perbedaan polaritas. Hasil pengujian dengan Gas Chromatography Mass Spectrometry (GCMS) hanya dilakukan pada sampel hasil ekstraksi dengan pelarut etanol, dan diperoleh luas area komponen pigmen tanin sebesar 7,15\%, kuinon sebesar 22,83\% dan flavanoid sebesar 0,36\% (Gambar 4).

Perbedaan kandungan ketiga komponen ini bisa disebabkan tiga faktor. Faktor pertama, etanol lebih polar dibandingkan akuades sehingga akan mudah mengekstrak komponen-komponen yang non polar. Ekstraksi dengan akuades hanya akan menarik sebagian zat tanin dan kuinon yang masih memungkinkan terambil dalam senyawa polar. Faktor kedua, konstanta dielektrik etanol lebih rendah dari akuades. Hal ini menyebabkan pelarut akuades akan lebih banyak menyerap energi dari microwave yang sedikit lebih tinggi daya ekstraknya dibandingkan etanol. Faktor ketiga, kandungan komponen-komponen tiap bahan tanaman berbeda, khususnya untuk jenis kayu-kayuan kadar flavanoid rendah. 

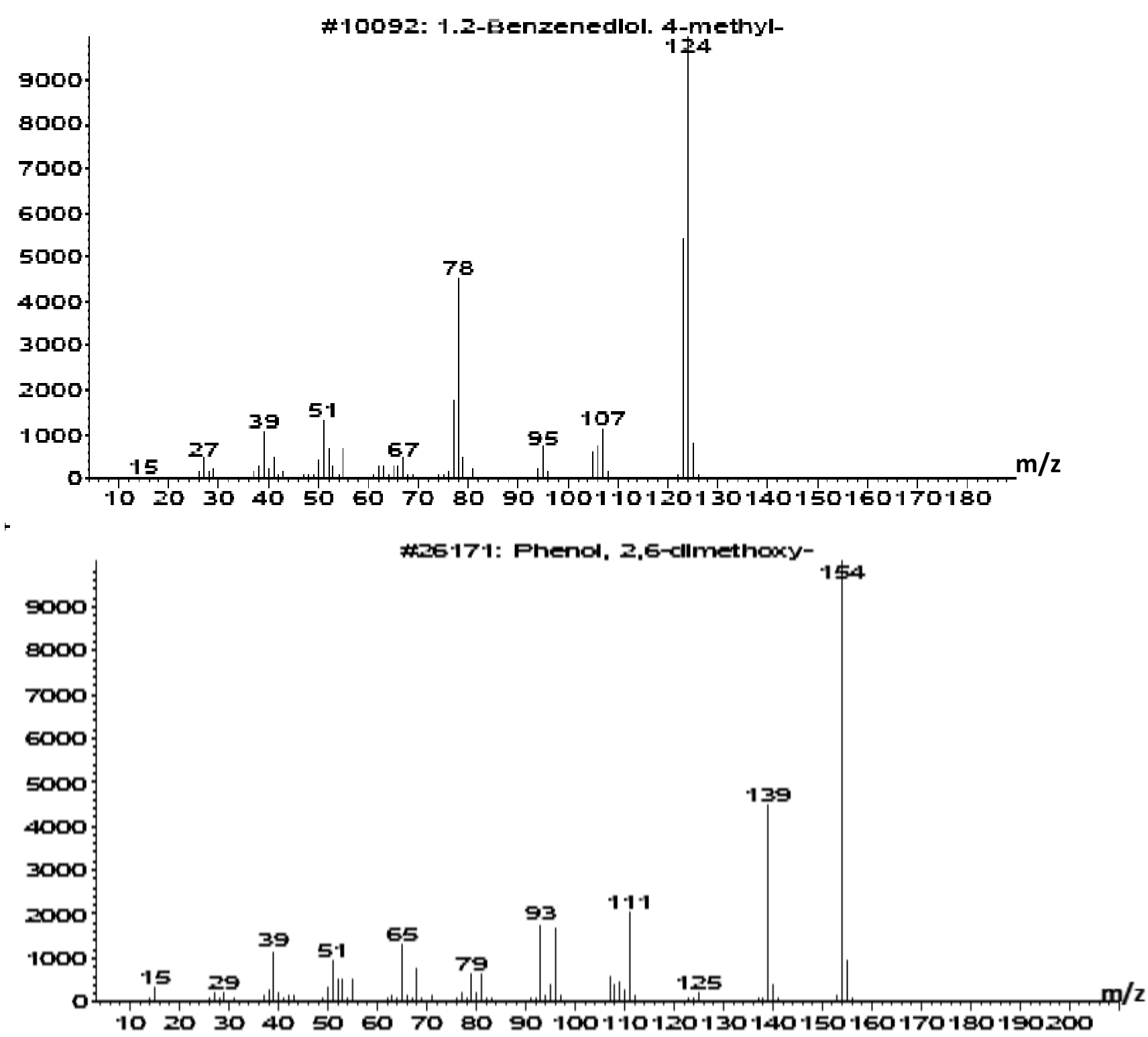

\#10753: 1,3,5-Benzenetrol

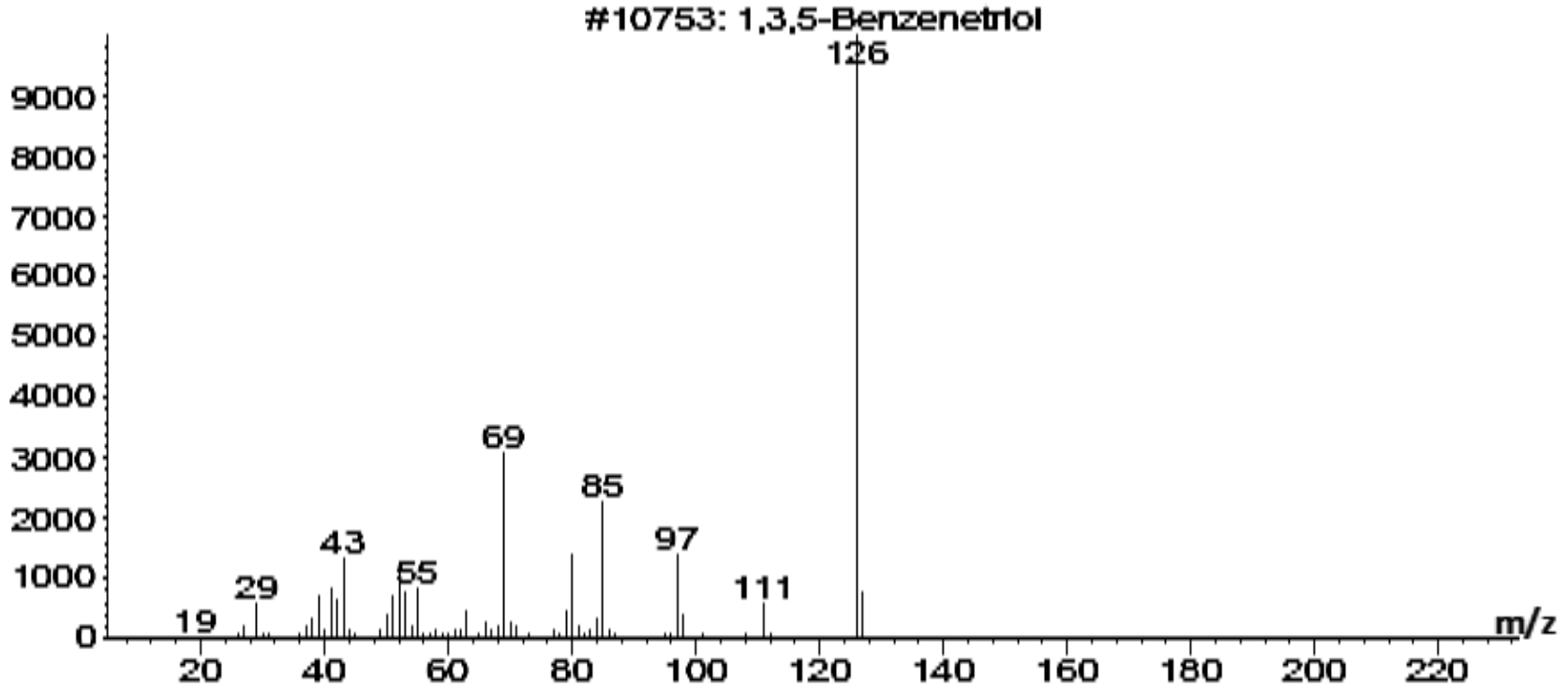

Gambar 4. Hasil analisis GCMS menunjukkan kandungan senyawa dalam ekstrak kayu bakau. 


\section{Kesimpulan}

Berdasarkan hasil penelitian yang telah dilakukan maka dapat disimpulkan bahwa ekstrak kulit kayu bakau mengandung tanin, flavonoid, dan kuinon secara kualitatif. Adanya uji ketahanan warna zat warna ekstrak kulit kayu bakau pada suasana basa menghasilkan warna lebih gelap dibandingkan dengan pencelupan dengan kondisi netral, asam, maupun pewarna sintetis. Etanol $96 \%$ merupakan jenis pelarut yang mampu memberikan persentase yield ekstrak yang lebih tinggi dibandingkan akuades dengan rasio terbaik $0,067(\mathrm{~g} / \mathrm{mL})$ pada daya 380 Watt dengan persentase yield mencapai 53,053\%.

\section{Ucapan Terima Kasih}

Penelitian ini dapat terlaksana dengan baik melalui kerjasama penelitian antara Laboratorium Proses, Institut Teknologi Sepuluh Nopember Surabaya dan Progam Studi Kimia, Universitas Ma Chung, Malang.

\section{Daftar Pustaka}

[1] S. Bahri, J. Jalaluddin, \& R. Rosnita, "Pembuatan Zat Warna Alami dari Kulit Batang Jamblang (Syzygium cumini) Sebagai Bahan Dasar Pewarna Tekstil", Jurnal Teknologi Kimia Unimal, vol. 6, no.1, pp. 10-19, 2017.

[2] F. G. Winarno, Kimia Pangan dan Gizi. Jakarta: PT. Gramedia, 1997.

[3] V. Sivakumar, J. Vijaeeswarri, Lakshmi, \& J. L. Anna, "Effective Natural Dye Extraction from Different Plant Materials using Ultrasound", Industrial Crops and Products, vol. 33, no. 1, pp. 116-122, 2011.

[4] N. Punrattanasin, M. Nakpathom, B. Somboon, N. Narumol, N. Rungruangkitkrai, \& R. Mongkholrattanasit, "Silk Fabric Dyeing with Natural Dye from Mangrove Bark (Rhizophora apiculata Blume) Extract", Industrial Crops and Products, vol. 49, pp. 122-129, 2013.

[5] S. Saxena \& A. S. M. Raja, "Natural Dyes: Sources, Chemistry, Application and Sustainability Issues", in Roadmap to Sustainable Textiles and Clothing, S. S. Muthu, Ed. Singapore: Springer, 2014, pp. 37-80.

[6] A. A. B. Putra, N. W. Bogoriani, N. P. Diantariani, \& N. L. U. Sumadewi, "Ekstraksi Zat Warna Alam dari Bonggol Tanaman Pisang (Musa paradiasciaca L.) dengan Metode Maserasi, Refluks, dan Sokletasi”, Jurnal Kimia, vol. 8, no. 1, pp. 113-119, 2014.

[7] S. Suhendry, E. Rasamah, \& E. Sukaton, "Karakteristik Ekstrak dari Kulit Kayu Bakau dengan Pelarut yang Berbeda", Ulin: Jurnal Hutan Tropis, vol. 1, no. 2, pp. 163-173, 2017.

[8] F. Yusro, "Rendemen Ekstrak Etanol dan Uji Fitokimia Tiga Jenis Tumbuhan Obat Kalimantan Barat," Tengkawang Jurnal IImu Kesehatan, vol. 1, no. 1, pp. 29-36, 2011.

[9] I. D. Febriana, S. Gala, \& M. Mahfud, "Ultrasound Assisted Extraction of Natural Dye from Jackfruit's Wood (Artocarpus heterophyllus): The Effect of Ethanol Concentration as a Solvent", in AIP Conference Proceedings, vol. 1840, no. 070004, 2017.

[10] L. Qadariyah, S. Gala, D. R. Widoretno, D. Kunhermanti, D. S. Bhuana, Sumarno, \& M. Mahfud, "Jackfruit (Artocarpus heterophyllus Lamk) Wood Waste as a Textile Natural Dye by Micowave-assisted Extraction Method", in AIP Conference Proceedings on International Seminar on Fundamental and Application of Chemical Engineering 2016, vol. 1840, no. 100007, 2017.

[11] I. D. Febriana, H. S. Kusuma, S. Gala, \& M. Mahfud, "The Effect of Temperature on Extraction of Swietenia mahagoni by Ultrasound-assisted Extraction (UAE) Method", ASEAN Journal of Chemical Engineering, vol. 16, no. 1, pp. 4550, 2016.

[12] A. Handaratri \& Y. Yuniati, "Kajian Ekstraksi Antosianin dari Buah Murbei dengan Metode Sonikasi dan Microwave", Reka Buana: Jurnal IImiah Teknik Sipil dan Teknik Kimia, vol. 4, no. 1, pp. 63-67, 2019.

[13] D. Jyothi, S. Khanam, \& R. S. Sultana, "Optimization of Microwave Assisted Extraction of Withanolides from Roots of Ashwagandha and Its Comparison with Conventional Extraction Method," International Journal of Pharmacy and Phamaceutical Sciences, vol. 2, no. 4, pp. 46-50, 2010.

[14] Y. Yuniati, P. E. Elim, R. Alfanaar, H. S. Kusuma, \& M. Mahfud, "Extraction of Anthocyanin Pigment from Hibiscus sabdariffa L. by Ultrasonic-Assisted Extraction", in IOP Conference on The $2^{\text {nd }}$ International Conference on Advanced Engineering and Technology 2020, vol. 1010, no. 012032, 2020.

[15] Y. R. Bintari \& H. Elyani, "Ekstraksi Senyawa Bioaktif dari Cladophora sp. dengan Metode Solvent Free Microwave Assisted Extraction (SFMAE)", Journal of Islamic Medicine Research, vol. 1, no. 1, 2017.

[16] S. Gala, S. Sumarno, \& M. Mahfud, "Microwave-assisted Extraction of Natural Dyes from Coleus atropurpureus Leaves: The Effect of Solvent," in MATEC Web of Conferences, vol. 156, no. 06011, 2018.

[17] D. K. Putri, I. E. P. Dewi, H. Kusuma, \& M. Mahfud, "Extraction of an Essential Oil from Fresh Cananga Flowers (Cananga odorata) using Solvent-Free Microwave Method," Journal of Chemical Technology and Metallurgy, vol. 54, no. 4, pp. 793-802, 2019. 
[18] S. Gala, S. Sumarno, \& M. Mahfud, "Comparison of Microwave and Conventional Extraction Methods for Natural Dyes in Wood Waste of Mahogany (Swietenia mahagoni)," Journal of Applied Engineering Science, vol. 4, no. 18, pp. 619$623,2020$.

[19] S. Noer, "Uji Kualitatif Fitokimia Daun Ruta angustifolia", Faktor Exacta, vol. 9, no.3, pp. 200-206, 2016.

[20] I. Hartati, "Isolasi Alkaloid dari Tepung Gadung (Dioscorea hispida Dennst) dengan Teknik Ekstraksi Berbantu Gelombang Mikro," Tesis, Universitas Diponegoro, Semarang, 2010.

[21] I. Illing, W. Safitri, \& E. Erfiana, "Uji Fitokimia Ekstrak Buah Dengen”, Jurnal Dinamika, vol. 8, no.1, pp. 66-84, 2017.

[22] S. V. Thite, Y. R. Chavan, V. T. Aparadh, and B. A. Kore, "Preliminary Phytochemical Screening of Some Medicinal Plants", International Journal of Pharmaceutical, Chemical and Biological Sciences, vol. 3, no. 1, pp. 87-90, 2013.

[23] W. Mangunwardoyo, L. Ismaini, \& E. S. Heruwati, "Analisis Senyawa Bioaktif dari Ekstrak Biji Picung (Pangium edule Reinw) Segar", Berita Biologi, vol. 9, no. 3, 2008.

[24] L. Wang \& C. L. Weller, "Recent Advances in Extraction of Nutraceuticals from Plants," Trends in Food Science and Technology, vol. 17, pp. 300-312, 2006.

[25] V. Mandal, Y. Mohan, \& S. Hemalatha, "Microwave Assisted Extraction - An Innovative and Promissing Extraction Tool for Medicinal Plant Research", Pharmacognosy Reviews, vol 1, no. 1, pp. 7-18, 2007.

[26] H. S. Kusuma \& M. Mahfud, "Pengaruh Daya dan Rasio Bahan pada Ekstraksi Kayu Cendana (Santalum album) dengan Metode Microwave Hydrodistillation: Optimasi Menggunakan Response Surface Methodology", Jurnal Teknik Kimia, vol. 10, no. 1, pp. 19-25, 2015.

[27] Noerati, Gunawan, M. Ichwan, \& A. Sumihartati, Teknologi Tekstil, Bahan Ajar Pendidikan dan Pelatihan Guru. Bandung: Sekolah Tinggi Teknologi Tekstil, 2013.

[28] A. Rosyida \& A. Zulfiya, "Pewarnaan Bahan Tekstil dengan Menggunakan Ekstrak Kayu Nangka dan Teknik Pewarnaannya untuk Mendapatkan Hasil yang Optimal," Jurnal Rekayasa Proses, vol. 7, no. 2, pp. 52-58, 2013. 